\title{
A new species of "gigantic" capsular fruits of Vaccinioideae from the Miocene of Idaho
}

\author{
MacKenzie Smith and Steven R. Manchester
}

\begin{abstract}
Large, capsular fruits of Ericaceae have been identified from the Emerald Creek site of the Middle Miocene Clarkia flora of northern Idaho. We recognize the morphological similarity of these fossils to fruits of the subfamily Vaccinioideae, specifically to the extant genus Oxydendrum (sourwood), which has a single extant species that lives primarily in the southeastern US and with members of the Lyonieae and Gaultherieae. We present a new species of vaccinioid capsular fruit as Juddicarpon benewahensis Smith and Manchester gen. et sp. nov. from an infructescence. The new species has fruits that are twice the size of those in extant Oxydendrum and outside the modern size range of vaccinioids with capsular fruit. This fossil is significant as the first record of fossil vacciniod fruit from Western North America.
\end{abstract}

MacKenzie Smith. Florida Museum of Natural History, 1659 Museum Rd., Gainesville, Florida 32611, USA. mackenziesmith@ufl.edu

Steven R. Manchester. Florida Museum of Natural History, 1659 Museum Rd., Gainesville, Florida 32611, USA. steven@flmnh.ufl.edu

Keywords: infructescence; Clarkia flora; Ericaceae; paleobotany; CT scan; western North America; Idaho

Submission: 16 March 2019. Acceptance: 9 September 2019.

\section{INTRODUCTION}

The Middle Miocene Clarkia flora of northern Idaho includes a diverse association of mixed mesophytic plants, most of which are exotic to the region today, but with relatives found in eastern North America (Manchester and Chen, 2006). Arborescent elements include several conifers such as Abies, Amentotaxus, Calocedrus, Cepha- lotaxus, Chamaecyparis, Cunninghamia, Keteleeria, Metasequoia, Picea, Pinus, Sequoia, Taxodium, Taxus and Thuja (Kvaček and Rember, 2000, 2007), various deciduous angiosperms such as Acer, Alnus, Cercidiphyllum, Fagus, Liquidambar, Liriodendron, Lithocarpus, Magnolia, Nyssa, Ostrya, Paliurus, Pseudofagus and Pterocarya (Smiley et al., 1975) and occasional ferns (Pinson

Smith, MacKenzie and Manchester, Steven R. 2019. A new species of "gigantic" capsular fruits of Vaccinioideae from the Miocene of Idaho. Palaeontologia Electronica 22.3.65, 1-7. https://doi.org/10.26879/982

palaeo-electronica.org/content/2019/2735-new-vaccinioideae-species

Copyright: October 2019 Paleontological Society.

This is an open access article distributed under the terms of Attribution-NonCommercial-ShareAlike 4.0 International (CC BY-NC-SA

4.0), which permits users to copy and redistribute the material in any medium or format, provided it is not used for commercial

purposes and the original author and source are credited, with indications if any changes are made.

creativecommons.org/licenses/by-nc-sa/4.0/ 
et al., 2018). Here, we recognize another element of this flora--the heath family, Ericaceae Juss.

The oldest known fossil occurrence of Ericaceae is Paleoenkianthus sayrevillensis from the Turonian (ca. $90 \mathrm{Ma}$ ) of New Jersey (Nixon and Crepet, 1993). Today the family has a global distribution (Tucker, 2009) and about 124 genera and 4,250 species (Christenhusz and Byng, 2016). Fruit can be a capsule, berry or drupe (Tucker, 2009). The subfamily Vaccinioideae Arn. of the Ericaceae includes 46 genera that are distributed worldwide except for Antarctica and found in almost every biome (Tucker, 2009). Its fruit morphologies are highly diverse and vary in all of the forms mentioned for Ericeaceae (Tucker, 2009). Here, we describe an infructescence conforming morphologically to the Vacciniodeae from the Middle Miocene of Idaho. This represents the first report of a vaccinioid from North America and one of the few occurrences of Ericaceae known from fossil fruits.

\section{MATERIALS AND METHODS}

The fossil (UI-P37-2019-1) is preserved in the lacustrine shale of the Clarkia lagerstätte upper oxidized zone (Unit 5 of Smiley et al., 1975; Smiley and Rember, 1985) from Emerald Creek, northern Idaho, USA $\left(47.032896^{\circ} \mathrm{N}, 116.338514^{\circ} \mathrm{W}\right)(\mathrm{Smi}-$ ley et al., 1975; Smiley and Rember, 1985) (Figures 1 and 2). These sediments belong to the middle Miocene Latah Formation) and are considered to be about roughly 16-15.4 Ma based on their position with respect to flows of the Priest Rapids Member (Wanapum Formation) of the Columbia River Basalt (Ladderud et al., 2015).

The fossil was microCT scanned with a GE Phoenix V|tome|xm240 CT Scanner at the Nanoscale Research Center, University of Florida, Gainesville, Florida. The resulting stack of tiff files was then processed in Avizo 9.0 Lite (FEI Visualization Science Group, Bordeaux, France) to generate an isosurface rendering. Subsequent processing of the isosurface utilized MeshLab (ISTI - CNR, Italy) using the lattice and depth map shaders. The specimen and scans were then compared with modern specimens of Oxydendrum arboreum using UF0202 from western Tennessee and UF0203 from the Indiana University arboretum, Bloomington, Indiana, both housed in the modern fruit collection at the Florida Museum of Natural History Paleobotany Collection, Gainesville, Florida and FLAS 32600 L.E. Arnold s.n. from Bristol, Florida, housed in the University of Florida Herbarium (FLAS), Gainesville, Florida.

\section{SYSTEMATIC PALEONTOLOGY}

Order ERICALES Bercht. and J.Presl, 1820

Family ERICACEAE Juss., 1789

Subfamily VACCINIOIDEAE Arn., 1832

Genus JUDDICARPON Smith and Manchester Juddicarpon benewahensis Smith and Manchester gen. et sp. nov.

Figures 3-4

Generic and specific diagnosis. Infructescence is a terminal raceme at least $5.5 \mathrm{~cm}$ long with pedicelate fruits drooping to one side of a moderately thick (ca. $1.9 \mathrm{~mm}$ thick) axis (secund raceme) with 10, five-valved ovate-elongate capsular fruits (Figure 3.1). Pedicels are curved and about $0.6 \mathrm{~cm}$ long and just under $2 \mathrm{~mm}$ in diameter (Figures 3.1$3,4.1-2)$. Pedicels have one visible bracteole scar (Figure 4.1). Each fruit has five hypogynous persistent, elongate and pointed sepals (Figure 4.3). Fruits are between $0.8-1.1 \mathrm{~cm}$ tall and $0.2-0.6 \mathrm{~cm}$ wide (with the majority of fruit at the maximum end

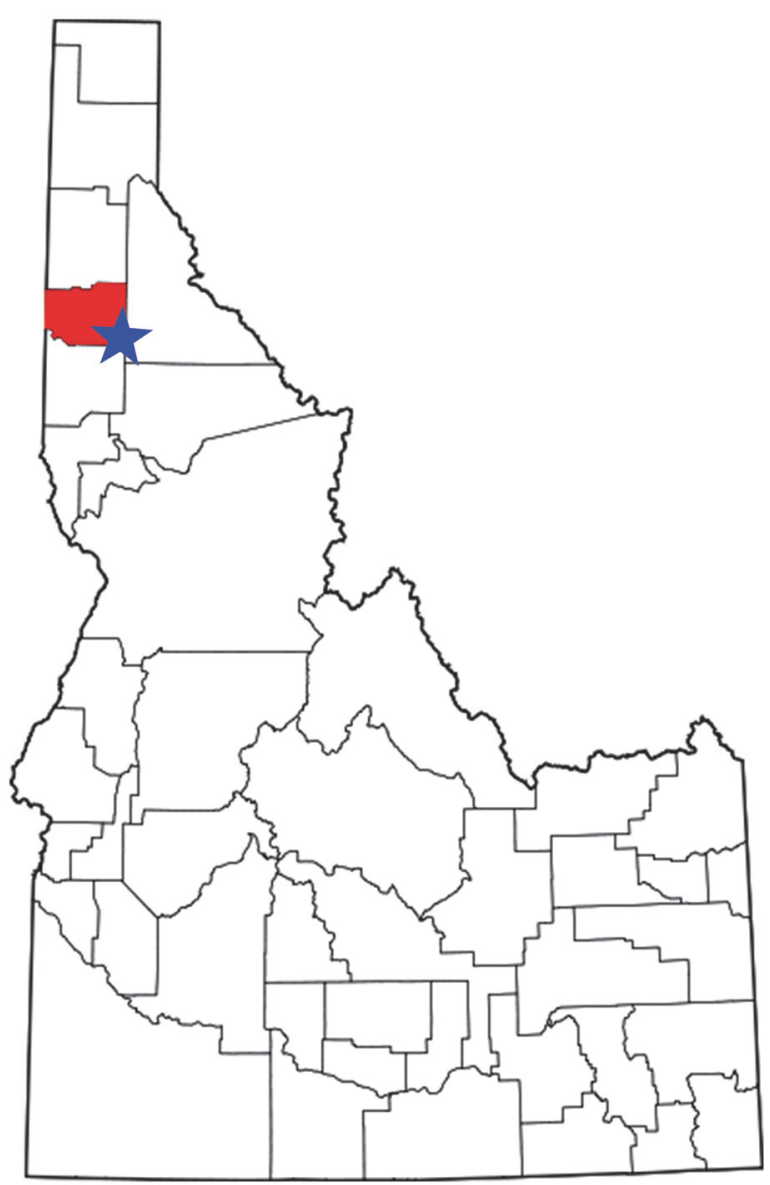

FIGURE 1. Map of Idaho showing position of the Emerald Creek site (star) in Benewah County (red filled). 


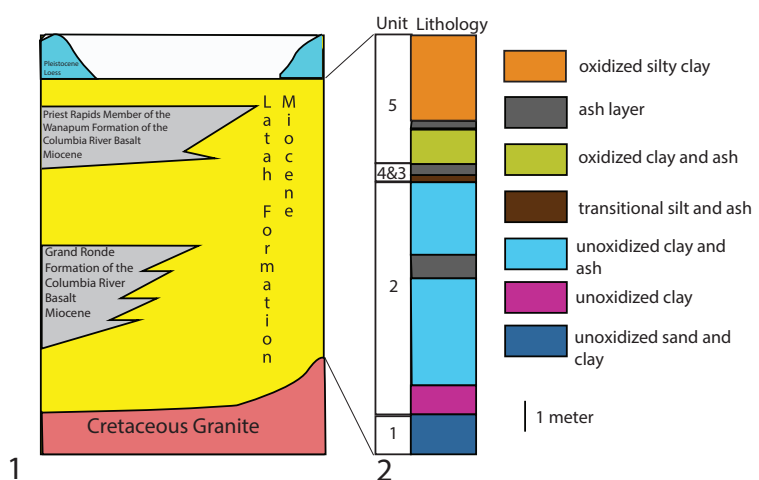

FIGURE 2. Stratigraphic column of the Latah Formation. 1, Geology at a regional scale from Fairley et al., 2006. 2, Stratigraphy of the Clarkia Beds from the Latah Formation from Calede et al. 2018 based on Smiley, Gray, and Huggins (1975) and Smiley and Rember (1985). Note not all units are visible at the Emerald Creek site.

of the previous ranges) with long valves lacking thickened sutures (Figures 3.1-3, 4.1-3) and a basal bulge between valves (Figure 4.1). One persistent style with truncated stigma is preserved and extends $6 \mathrm{~mm}$ beyond the fruit apex (Figure 3.1-2). Etymology. The genus Juddicarpon honors Walter S. Judd, who shared his expertise on extant Ericaceae with us. The epithet benewahensis refers to Benewah County, Idaho, where the fossil was found.

Type locality. Emerald Creek, ID (Clarkia flora)

Age. Burdigalian-Langhian (16-15.4 Ma)

Holotype. Specimen UI-P37-2019-1 housed with the herbarium paleobotanical collections at University of Idaho.

\section{DISCUSSION}

The specimen is broken in such a way as to reveal the fruits in longitudinal fracture. In most of the attached fruits only three valves can be counted, but five are inferred from the symmetry (Figures 3.1-3, 4.1-4). Five-valved capsular fruits with persistent hypogynous sepals are present and relatively common within the Ericaceae (e.g., Enkianthus, Pieris and Lyonia), however, the Ericaceae are not the only plant family to have this combination of characters (e.g., other families in the Ericales such as Theaceae and tribe Hibisceae in the family Malvaceae) (Kron et al., 1999; Pfeil et al., 2002; Luna and Ochoterena, 2004). We distinguish this fossil from Theaceae because fruits of that family are generally borne solitary rather than in infructescences. We distinguish it from the Malvaceae based on the combination of features discussed below.
Within the Ericaceae, many members of Vacciniodeae have flowers and fruits borne mainly on one side of the axis, i.e., in secund arrangement (e.g., Oxydendrum, Pieris, Lyonia, Leucothoë and Eubotrys) (pers. obs.). Because the basal portion of the inflorescence was not collected, it is possible that instead of a raceme it could be one unit of a larger panicle. Among the extant genera of Vaccinioideae with secund infructesences, only the monotypic Oxydendrum arboreum (L.) DC has ovate to elongate fruits, non-thickened sutures, a terminal peduncle and occasional bulges at the base between the valves (Figure 4.5-8) (Kron et al., 1999; Kron et al., 2002). Even though septa were not preserved, we interpret the fruit to be loculicidal because the valves open through the basal bulges, a position which seems unlikely for a septum to run through. Loculicidal fruits are a consistent character in the dry-fruited genera of Vaccinioideae. We interpret the infructescence as being determinate because the pedicel of the terminal fruit does not seem to curve laterally. These combined characters also do not exist in the Theaceae or Malvaceae. Thus, we infer that the fossil is closely related to the extant genus Oxydendrum.

When comparing the fossil to modern Oxydendrum arboreum, a difference that is noticed is the larger size of fossil infructescence and fruits. The pedicels are $2 \mathrm{~mm}$ thick in the fossil but less than $1 \mathrm{~mm}$ in both studied specimens of $O$. arboreum. In the modern fruit height ranges from 3-5 $\mathrm{mm}$ but in the fossil this ranges from $8-11 \mathrm{~mm}$. Additionally, the maximum width for 0 . arboreum fruits is $4 \mathrm{~mm}$, but in the fossil it is $6 \mathrm{~mm}$. Fruit number differs between modern specimens and the fossil with $O$. arboreum having more than 10 fruits and the fossil only having 10 observable fruits. Because of the size difference observed in both the fruits and pedicels and the fruit number, it is relatively easy to distinguish the fossil from $\mathrm{O}$. arboretum.

We extended our comparison to include other genera of the Vaccinioideae with capsular fruits such as Lyonia, Agarista, Pieris and Leucothoë. For phylogenetic context, an ericalean phylogeny by Schwery et al. (2015) shows Vaccinieae and Andromedeae (which includes Zenobia) as a clade with Gaultherieae (which includes Leucothoë) sister to it, Oxydendreae sister to that and Lyonieae (which includes Pieris and Lyonia) sister to that. It is possible for Lyonia to have secund racemes (e.g., Lyonia ligustrina var. ligustrina though capsules are globose) and to have elongated capsules (e.g., Lyonia mariana although it does not have a 

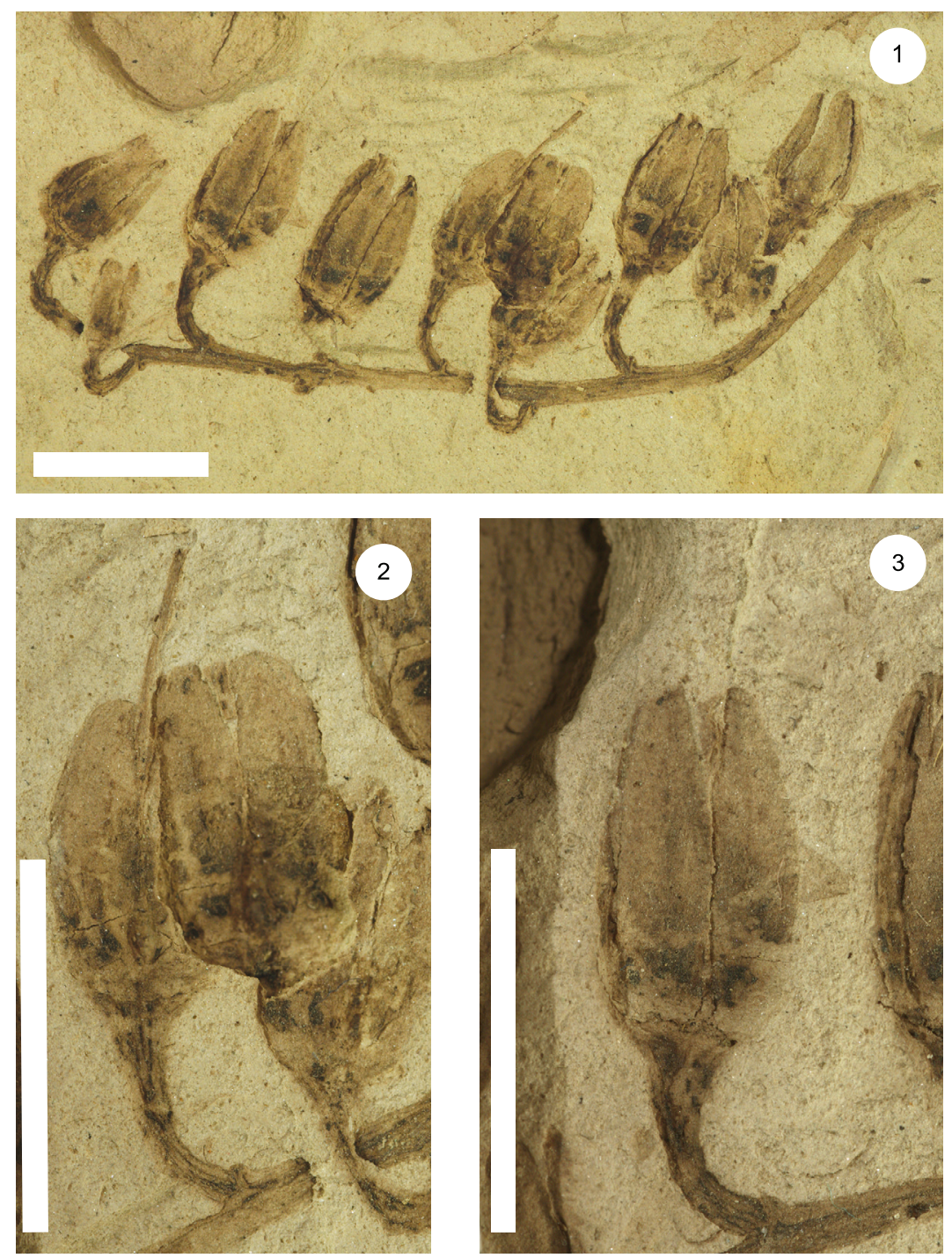

FIGURE 3. Holotype, UI-P37-2019-1 Juddicarpon benewahensis sp. nov. Smith and Manchester from the Miocene of Idaho. All scale bars equal $1 \mathrm{~cm}$. 1, Secund raceme with a terminal fruit and ten capsules total. All fruit are five-valved ovate-elongated capsules. 2, A fruit with curved pedicel and persistent style. 3, Fruit lacking persistent style.

secund raceme). However, fruit size does not vary much within species for the dry fruit of Vaccinioideae. Only one specimen, a Lyonia (FLAS 53054) unidentified to species level, had varying fruit size on the same branch during our search. Because there is only one living species from which to infer useful characters for identification in the Oxydendreae and in view of the morphological variability within the rest of Vaccinioideae we feel that the combined traits warrant a new genus and species within the Vaccinioideae. It is noteworthy that these fossil fruits are larger than any we have observed among extant Vaccinioideae. Larger capsular fruits occur in other clades of Ericaceae, such as in Rhododendron, but the observed morphology fits better with the Vaccinioideae. It seems possible that this extinct genus corresponds to a lineage that combines features of more than one modern clade within Ericaceae. We suppose that the large fruit size may be a plesiomorphic condition within Vaccinioideae, but more fossils and a more comprehensive morphological phylogenetic analysis would be needed to test this.

There are no living vaccinioids in Idaho today with capsular fruit. Instead, the modern genera are located primarily in eastern North America and Asia. A notable exception is Leucothoë davisiae from California and Oregon (USDA, n.d.). It is possible that it went extinct due to the region drying 

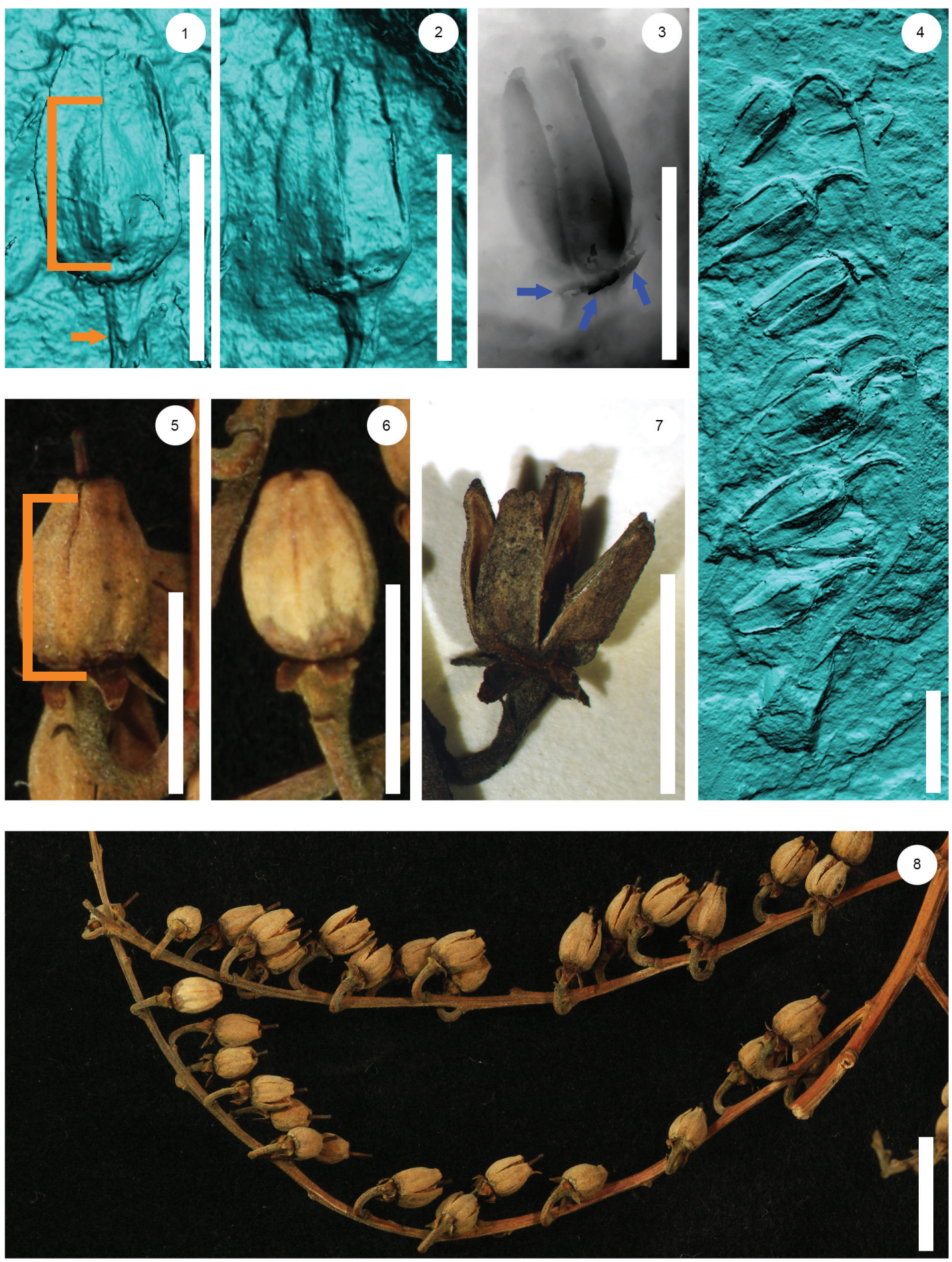

FIGURE 4. 1-2, $\mu \mathrm{CT}$ scan with lattice shading of Juddicarpon benewahensis scale bars equal $1 \mathrm{~cm}$. 1, Fruit with prominent basal bulge in orange bracket between valves and orange arrow pointing at bracteole scar. 2, Fruit with less prominent basal bulge between valves. 3, CT scan of $J$. benewahensis with depth map shading showing persistent perianth in blue arrows. Scale bar $1 \mathrm{~cm} .4, C T$ scan with lattice shading of the entire raceme of $J$. benewahensis with capsules showing two-three valves. Scale bar equals $1 \mathrm{~cm}$. 5-6, UF0203 Oxydendrum arboreum fruit showing basal bulge between valves. Scale bars equal $0.5 \mathrm{~cm}$. 5, Fruit with persistent style and prominent basal bulge between valves between orange bracket. 6, Fruit with partial persistent style and less prominent basal bulge. 7, 0 . arboreum FLAS 32600 open fruit with no style and lacking basal bulge. Scale bar equals $0.5 \mathrm{~cm}$. 8, UF0203 O. arboreum showing secund raceme. Scale bar $1 \mathrm{~cm}$. 
and having no refugia to escape because of being surrounded by mountains.

We take this opportunity to comment on the fossils used for calibration of the phylogeny of Ericaceae. Schwery et al. (2015) used the fossil leaf, Vaccinium creedensis Axelrod (1987), as a dating calibration point for Vaccinium. However, this species was already transferred to Berberis by Wolfe and Schorn (1990) based on seven diagnostic characters and is thus inapplicable for calibrating ericalean phylogeny. In general, the assignment of fossil leaves to particular extant genera of Ericaceae should be accepted with caution because of the convergence of leaf architectural patterns both within and outside the family. Fossil fruits and flowers, when available, can provide greater systematic resolution within the Ericaceae.

Few fossil fruit from the Vaccinioideae are known and none were reported previously from North America. European examples include Lyonia danica Friis from the Miocene of Denmark and Germany (Friis, 1985; Mai, 2001), Zenobia fasterholtensis Friis from the Miocene of Denmark (Friis, 1985), Eubotrys sp. from the Miocene of Denmark (Friis, 1985), and Leucothoë narbonensis Mai from the Oligocene of Germany (Mai, 1998). Andromeda brunnea Dorofeev was recognized from the Oligocene of Siberia (Dorofeev, 1963). J. benewahensis is more elongated than these fruit and is at least twice their size. Juddicarpon is the first fossil fruit from this subfamily in North America.

\section{CONCLUSION}

Juddicarpon benewahensis is the first fossil vaccinioid fruit to be recognized from North America. Its unique combination of characters and large size make it difficult to place precisely within the Vaccinioideae, adding to the subfamily's complex evolutionary history, but it helps explain the timing of how this successful group spread.

\section{ACKNOWLEDGEMENTS}

We thank Dr. W. Rember for making the specimen available for study, Dr. W. Judd for his help with the identification of this specimen and K. Perkins for his assistance at the University of Florida Herbarium. We thank T. Lott for his help in reviewing and editing the proofs.

\section{REFERENCES}

Arnott, G.A.W. 1832. Botany, p. 118. In Napier, M. (ed.), Encyclopaedia Britannica, vol. 7. A \& C Black, Edinburgh.

Axelrod, D.I. 1987. The late Oligocene Creede flora, Colorado. University of California Publications in Geological Sciences, 130:1-236.

Berchtold, F. and Presl, J.S. 1820. O Prirozenosti Rostlin. Praha, Prague.

Calede, J.J.M., Orcutt, J.D., Kehl, W.A., and Richards, B.D. 2018. The first tetrapod from the mid-Miocene Clarkia lagerstätte (Idaho, USA). PeerJ, 6:e4880 https://doi.org/10.7717/ peerj.4880

Christenhusz, M.J.M. and Byng, J.W. 2016. The number of known plants species in the world and its annual increase. Phytotaxa, 261(3):201-217. https://doi.org/10.11646/ phytotaxa.261.3.1

de Candolle, A.P. 1839. Prodromus Systematis Naturalis Regni Vegetabilis, Sive, Enumeratio Contracta Ordinum Generum Specierumque Plantarum huc Usque Cognitarium, Juxta Methodi Naturalis, Normas Digesta. Sumptibus Sociorum Treuttel et Würtz, Paris. https:// doi.org/10.5962/bhl.title.286.

de Jussieu, A.L. 1789. Antonii Laurentii de Jussieu Genera Plantarum: Secundum Ordines Naturales Disposita, Juxta Methodum in Horto Regio Parisiensi Exaratam, Anno M.DCC.LXXIV. Apud Viduam Herissant et Theophilum Barrois, Paris. https://doi.org/10.5962/ bhl.title.284

Dorofeev, P.I. 1963. Tretichnye Flory Zapadnoi Sibiri. Akad. Nauk, Moscow/Leningrad.

Fairley, J.P., Solomon, M.D., Hinds, J.J., Grader, G.W., Bush, J.H., and Rand, A.L. 2006. Latah County Hydrologic Characterization Project. Idaho Department of Water Resources.

Friis, E.M. 1985. Angiosperm fruits and seeds from the Middle Miocene of Jutland (Denmark). The Royal Danish Academy of Sciences and Letters, 24(3):3-165. 
Kron, K.A., Judd, W.S., and Crayn, D.M. 1999. Phylogenetic analyses of Andromedeae (Ericaceae subfam. Vaccinioideae). American Journal of Botany, 86(9):1290-1300. https:// doi.org/10.2307/2656777

Kron, K.A., Judd, W.S., Stevens, P.F., Crayn, D.M., Anderberg, A.A., Gadek, P.A., Quinn, C.J., and Luteyn, J.L. 2002. Phylogenetic classification of Ericaceae: molecular and morphological evidence. The Botanical Review, 68(3):335-423.

Kvaček, Z. and Rember, W.C. 2000. Shared Miocene conifers of the Clarkia flora and Europe. Acta-Universitatis Carolinae Geologica, 1:75-86.

Kvaček, Z. and Rember, W.C. 2007. Calocedrus robustior (Cupressaceae) and Taxus schornii (Taxaceae): two new conifers from the middle Miocene Latah Formation of northern Idaho. Paleobios, 27(2):68-79.

Ladderud, J.A., Wolff, J.A., Rember, W.C., and Brueseke, M.E. 2015. Volcanic ash layers in the Miocene Lake Clarkia beds: Geochemistry, regional correlation, and age of the Clarkia flora. Northwest Science, 89:309-323.

Luna, I. and Ochoterena, H. 2004. Phylogenetic relationships of the genera of Theaceae based on morphology. Cladistics, 20(3):223-270. https://doi.org/10.1111/j.1096-0031.2004.00024.x

Mai, D.H. 1998. Contribution to the flora of the middle Oligocene Calau Beds in Brandenburg, Germany. Review of Palaeobotany and Palynology, 101:43-70.

Mai, D.H. 2001. Die mittelmiozänen und obermiozänen Floren aus der Meuroer und Raunoer Folge in der Lausitz. Teil II: Dicotyledonen. Palaeontographica Abteilung B, 257:35-174.

Manchester, S.M. and Chen, I. 2006. Tetracentron fruit from the Miocene of Western North America. International Journal of Plant Sciences, 167(3):601-605. https://doi.org/10.1086/ 503206

Nixon, K.C. and Crepet, W.L. 1993. Late Cretaceous fossil flowers of Ericalean affinity. American Journal of Botany, 80(6):616-623. https://doi.org/10.2307/2445430

Pfeil, B.E., Brubaker, C.L., Craven, L.A., and Crisp, M.D. 2002. Phylogeny of Hibiscus and the tribe Hibisceae (Malvaceae) using chloroplast DNA sequences of ndhF and the rpl16 intron. Systematic Botany, 27(2):333-351.

Pinson, J.B., Manchester S.R., and Sessa, E.B. 2018. Culcita remberi sp. nov., an understory fern of Cyatheales from the Miocene of northern Idaho. International Journal of Plant Sciences, 179:635-639. https://doi.org/10.1086/698938

Schwery, O., Onstein, R.E., Bouchenak-Khelladi, Y., Xing, Y., Carter, R.J., and Linder, H.P. 2015. As old as the mountains: the radiations of the Ericaceae. New Phytologist, 207(2):355-367. https://doi.org/10.1111/nph.13234

Smiley C.J., Gray J., and Huggins, L.M. 1975. Preservation of Miocene fossils in unoxidized lake deposits, Clarkia, Idaho. Journal of Paleontology, 49(5):833-844.

Smiley, C.J. and Rember W.J. 1985. Physical setting of the Miocene Clarkia fossil beds, northern Idaho, p. 11-31. In Smiley, C.J. (ed.), Late Cenozoic History of the Pacific Northwest. Pacific Division, AAAS, San Francisco.

Tucker, G.C. 2009. Ericaceae. In Flora of North America Editorial Committee, (eds.), Flora of North America North of Mexico, vol. 8. New York and Oxford. http://www.efloras.org/ florataxon.aspx?flora_id=1\&taxon_id=10316 accessed 1 December 2018.

United States Department of Agriculture. 2018. Leucothoë davisiae Torr. ex A. Gray Sierra laurel. https://plants.usda.gov/core/profile?symbol=LEDA accessed 1 December 2018.

Wolfe, J.A. and Schorn, H.E. 1990. Taxonomic revision of the Spermatopsida of the Oligocene Creede Flora, Southern Colorado. US Geological Survey Bulletin 1923. https://doi.org/ 10.3133/b1923 